\title{
Residual Effects of Organic and NPK Fertilizers on Maize Performance at Different Soil pH Levels
}

\author{
B.O. Unagwu, C.L.A. Asadu, and P. I. Ezeaku \\ Department of Soil Science, University of Nigeria, Nsukka, Nigeria.
}

\begin{abstract}
Acid soils are highly weathered and are usually excessive in soluble aluminum and manganese and deficient in phosphorous, calcium, magnesium and molybdenum, which may cause their reduced uptake and lead to nutrient imbalances in plants. To address this problem, a field study was carried out in 2012 to evaluate the residual effects of combined rates of poultry manure (PM) and NPK 15-15-15 fertilizers on responses of maize (Zea mays $L$ ) in a soil limed to different $p H$ levels. The treatments were four levels of soil $p H: p H 5.5$ (control), pH 6.0, pH 6.5and pH 7.0 and six levels of combined PM and NPK 15-15-15 fertilizer: T1 (200 kg/ha NPK + 6 t/ha PM);T2 (300 kg/ha NPK + 4 t/ha PM), T3 (400 kg t/ha NPK + 2 t/ha PM); T4 (400 t/ha NPK only), T5 (8 t/ha PM only) and T6 (Control) arranged in a $6 \times 4$ factorial in randomized complete block design (RBCD) with three replications. The results showed that Treatment T2 (8 t/ha PM only) significantly $(P<0.05)$ gave the highest dry matter yield while T2 (300 kg/ha NPK + 4t/ha PM) had the least dry matter yield. Liming also increased the maize dry yield with soil limed to pH 6.0 having the highest dry matter. It was therefore concluded that for second season planting, maize can be efficiently produced in sandy loam ultisols previously applied with treatments T5 (8t/ha PM) and limed to $\mathrm{pH}$ 6.0.
\end{abstract}

Key words: Soil pH, Maize, NPK, fertilizer, Poultry manure, Ultisol

\section{Introduction}

Soil acidity is a major factor of soil degradation which has detrimental effects on plant growth by affecting plant nutrient availability and plant development according to Tisdale et.al, (1993) and Rengel et al., (2003). Acid soils are usually excessive in soluble $\mathrm{Al}$ and $\mathrm{Mn}$ and deficient in $\mathrm{P}, \mathrm{Ca}, \mathrm{Mg}$ and $\mathrm{Mo}$, that may cause their reduced uptake and lead to nutrient imbalances in plants (Foy, 1984). Soil acidification and indirectly nutrient depletion is an on-going natural process and according to Baligar and Fageria (1997), it covers extensive areas in the tropical and temperate zones. The most serious of these is that at low pHs; acids $\left(\mathrm{H}^{+}\right)$can release soluble aluminium $(\mathrm{Al})$ and manganese $(\mathrm{Mn})$ from soil mineral which have direct toxic effects on many plants (Beukes, 2000).

Lime application is one of the ancient agricultural practices to ameliorate soil acidity. Several liming materials such as crushed limestone $\left(\mathrm{CaCO}_{3}\right)$, dolomitic lime $\left(\mathrm{CaMgCO}_{3}\right)$ slaked lime $\left(\mathrm{Ca}(\mathrm{OH})_{2}\right)$, quick lime $(\mathrm{CaO})$ etc., can be used to reduce soil acidity either singly or in combined form. Studies have shown that lime application reduces the acidity of the soil by counteracting the effects of excess $\mathrm{H}^{+}$and $\mathrm{Al}^{3+}$ ions (Fageria and Baligar, 2008). Naidu et al., (1990) reported that liming the soil has several benefits which include, reducing the toxicity effects of some micro elements by lowering their concentrations and increasing the availability of plant nutrients such as $\mathrm{Ca}, \mathrm{P}, \mathrm{Mo}$, and $\mathrm{Mg}$ in the soil and reducing the solubility and leaching of heavy metals (Lindsay, 1979; Sauvé et al., (2000). Lungu and et al., (1993) also reported that liming can be ineffective on some tropical soils because of the large amount of leaching. Kisinyo et al. (2009) reported that higher lime rates (4 and 6 ton lime/ha) had longer term residual effects on soil $\mathrm{pH}, \mathrm{P}$ availability and maize yields compared to the lower rate ( 2 tons lime/ha). According to them shorter term residual effect of the lower lime rates observed was due to rapid depletion of $\mathrm{Ca}^{2+}$ ions in the material applied. Residual effect of lime depends on the amount of $\mathrm{Ca}^{2+}$ and $\mathrm{Mg}^{2+}$ ions remaining in the liming material that can still displace residual soil acidity ( $\mathrm{Al}^{3+}$ and $\mathrm{H}^{+}$ions) (Shainberg et. al, (1989).

The et al., (2006) reported that combined lime and P fertilizer treatments gave higher soil P availability and maize yields compared to sole treatment application. Other researches similarly reported that combined lime and TSP fertilizer applications increased the soil pH, P availability and maize grain yield (Kisinyo et al., 2005; Kisinyo et al., 2005; Buresh et al., 1997). Numerous researches have shown the positive effect of liming on crops grain yield (Kovacevic et al., 2006a; Antunovic, 2008; Rastija et al., 2010).

There are many research works on the effect of organic or inorganic fertilizers on crop growth but there is rarely available information on the residual effect of combined application of organic and inorganic fertilizers in a soil limed to different $\mathrm{pH}$ levels. Therefore, the objective of this research was to evaluate the residual effect of application of organic and inorganic fertilizers on maize performance in a soil limed to different $\mathrm{pH}$ levels. 


\section{Materials and Methods}

The study was done at the University of Nigeria Research Farm, Nsukka located at latitude $06^{\circ} 52^{1} \mathrm{~N}$ and longitude $07^{\circ} 24^{1} \mathrm{E}$. The site elevation is $447 \mathrm{~m}$ above the sea level. The rainfall pattern is bimodal: the rainy (April - October) and the dry seasons (November - March). The relative humidity is rarely below $60 \%$ (Asadu et. al, 2002). The soil is very deep, dark-reddish brown at the top layer and reddish in the subsoil. Its clay mineralogy is composed mainly of kaolinite and quartz (Akamigbo and Igwe, 1990).

\section{Field trial}

After ploughing and harrowing, the lime requirement of the soil was determined using the procedure described by Shoemaker et al. (1961). Lime, calcium oxide $(\mathrm{CaO})$, was broadcast and mixed thoroughly into the soil using hoes and left for one month to allow for proper integration with the soil so as to bring the soil to the required $\mathrm{pH}$ levels (pH6, $\mathrm{pH} 6.5$ and $\mathrm{pH} 7.0)$.

The treatments used in the previous trial were four levels of soil pH: $\mathrm{pH} 5.5$ (control), $\mathrm{pH} 6.0, \mathrm{pH} 6.5$ and $\mathrm{pH} 7.0$ and six rates of combined poultry manure (PM) and NPK 15-15-15 fertilizer: T1 (200 kg/ha NPK + 6 t/ha PM); T2 (300 kg/ha NPK + 4 t/ha PM), T3 (400 kg t/ha NPK + 2 t/ha PM); T4 (400 t/ha NPK only), T5 (8 t/ha PM only); T6 (Control). The experiment was arranged in a $6 \times 4$ factorial in Randomized Complete Block Design (RCBD) with three replications. During the second season planting (residual planting), each of the previous experimental plots was manually weeded and ploughed. Thereafter, maize (Zea mays) M-S yellow variety (test crop) was planted at a planting distance of $75 \mathrm{~cm} \times 25 \mathrm{~cm}$ with a plant population of 53,333 plants/ha. There was no any other fertilizer treatment applied during the residual planting.

\section{Soil Sampling and Analysis}

Top soil of $0-15 \mathrm{~cm}$ collected, air dried and sieved with a $2 \mathrm{~mm}$ sieve. Soil $\mathrm{pH}$ was determined using $\mathrm{pH}$ meter in a soil solution ratio of 1:2.5. Available phosphorus was determined using Bray II method as described by Bray and Kurtz (1945). Exchangeable calcium, magnesium, sodium and potassium were extracted with NH4OAc. Calcium and magnesium were determined using Ethylenediamine tetra-acetic acid (EDTA) titration method while potassium and sodium was determined by flame photometer. Organic carbon was determined by dichromate oxidation method of Walkley and Black (1934) and corrected to organic matter by multiplying with a correction factor of 1.724. Total nitrogen was determined using the Kjeldhal method as described by Bremner, (1996). Cation exchange capacity was determined titrimetrically using $0.01 \mathrm{~N} \mathrm{NaOH}$. Exchangeable acidity was determined titrimetrically using $0.05 \mathrm{~N} \mathrm{NaOH}$. Bulk density was determined by core method as described by Anderson and Ingram (1993).

\section{Data Analysis}

The data collected were subjected to the analysis of variance (ANOVA) using GENSAT 2007 discovery edition and means were separated with least significant difference (LSD) at 0.05 probability levels.

III. Results And Discussion

Table1. Initial Soil Chemical Properties before Amendments in the First Planting Season

\begin{tabular}{|c|c|c|c|c|c|c|c|c|c|c|c|}
\hline $\begin{array}{l}\mathrm{pH} \\
\mathrm{H}_{2} \mathrm{O}\end{array}$ & $\begin{array}{l}\mathrm{pH} \\
\mathrm{KCl}\end{array}$ & $\begin{array}{l}\text { Total N } \\
\left(\mathrm{gkg}^{-1}\right)\end{array}$ & $\begin{array}{l}\mathrm{OM} \\
\left(\mathrm{gkg}^{-1}\right)\end{array}$ & $\mathrm{Ca}$ & $\mathrm{Mg}$ & $\begin{array}{l}\mathrm{K} \\
\text { cmolkg }^{-1}\end{array}$ & $\mathrm{Na}$ & $\mathrm{Al}$ & EA & CEC & $\begin{array}{l}\text { Avail. } \\
\left(\mathrm{mgkg}^{-1}\right)\end{array}$ \\
\hline 5.5 & 4.7 & 0.35 & 11.0 & 4.3 & 1.6 & 0.07 & 0.22 & 0.8 & 1.2 & 6.2 & 14.34 \\
\hline
\end{tabular}

Table 1 shows the soil conditions before treatments application during the first planting season. The soil is strongly acidic with relatively low values of exchangeable calcium, CEC, available phosphorous, exchangeable bases and total nitrogen. The low soil nutrient could be due to leaching losses as a result heavy rainfall that characterised the study area. 
Table2. Effect Treatment Application on Soil Chemical Properties after the First Planting Season.

\begin{tabular}{|c|c|c|c|c|c|c|c|c|c|c|c|c|}
\hline Treatments & $\begin{array}{l}\mathrm{pH} \\
\mathrm{H}_{2} \mathrm{O}\end{array}$ & $\begin{array}{l}\mathrm{pH} \\
\mathrm{KCl}\end{array}$ & $\begin{array}{l}\text { Total } \\
\mathrm{N} \\
\left(\mathrm{gkg}^{-1}\right)\end{array}$ & $\begin{array}{l}\mathrm{OM} \\
\left(\mathrm{gkg}^{-1}\right)\end{array}$ & $\mathrm{Ca}$ & $\mathrm{Mg}$ & $\mathrm{K}$ & $\begin{array}{l}\mathrm{Na} \\
\mathrm{cmol} / \mathrm{kg}\end{array}$ & $\mathrm{Al}$ & EA & CEC & $\begin{array}{c}\text { Avail. P } \\
\left(\mathrm{mgkg}^{-1}\right)\end{array}$ \\
\hline Fertilizer & & & & & & & & & & & & \\
\hline $\begin{array}{l}\text { T1 } \\
\text { T2 } \\
\text { T3 } \\
\text { T4 } \\
\text { T5 } \\
\text { T6 }\end{array}$ & $\begin{array}{l}6.0 \\
6.1 \\
5.9 \\
6.1 \\
5.8 \\
6.0\end{array}$ & $\begin{array}{l}5.7 \\
5.4 \\
5.2 \\
5.5 \\
5.4 \\
5.1\end{array}$ & $\begin{array}{l}0.37 \\
0.30 \\
0.39 \\
0.36 \\
0.42 \\
0.28\end{array}$ & $\begin{array}{l}14.7 \\
13.4 \\
15.3 \\
15.0 \\
14.9 \\
14.5\end{array}$ & $\begin{array}{l}3.27 \\
3.58 \\
3.27 \\
3.62 \\
3.25 \\
3.00\end{array}$ & $\begin{array}{l}1.50 \\
1.55 \\
1.00 \\
0.89 \\
0.85 \\
0.88\end{array}$ & $\begin{array}{l}0.10 \\
0.08 \\
0.08 \\
0.12 \\
0.11 \\
0.10\end{array}$ & $\begin{array}{l}0.21 \\
0.21 \\
0.20 \\
0.18 \\
0.20 \\
0.20\end{array}$ & $\begin{array}{l}0.36 \\
0.45 \\
0.38 \\
0.46 \\
0.39 \\
0.53\end{array}$ & $\begin{array}{l}1.40 \\
1.18 \\
1.23 \\
1.25 \\
1.15 \\
1.45\end{array}$ & $\begin{array}{l}6.80 \\
6.85 \\
7.10 \\
6.65 \\
6.70 \\
6.90\end{array}$ & $\begin{array}{l}15.04 \\
16.55 \\
16.44 \\
16.32 \\
15.97 \\
12.94\end{array}$ \\
\hline $\begin{array}{l}\text { F-LSD } \\
(p<0.05)\end{array}$ & 0.17 & 0.14 & 0.07 & NS & NS & 0.43 & 0.02 & NS & 0.11 & NS & NS & NS \\
\hline $\begin{array}{l}\text { pH (Lime) } \\
\text { pH } 5.5 \\
\text { pH } 6.0 \\
\text { pH } 6.5 \\
\text { pH } 7.0\end{array}$ & $\begin{array}{l}5.4 \\
5.6 \\
6.1 \\
6.8\end{array}$ & $\begin{array}{l}4.7 \\
5.1 \\
5.4 \\
6.3\end{array}$ & $\begin{array}{l}0.51 \\
0.30 \\
0.30 \\
0.29\end{array}$ & $\begin{array}{l}15.5 \\
17.3 \\
13.8 \\
11.9\end{array}$ & $\begin{array}{l}2.10 \\
3.50 \\
3.60 \\
4.13\end{array}$ & $\begin{array}{l}1.63 \\
0.41 \\
1.29 \\
1.11\end{array}$ & $\begin{array}{l}0.14 \\
0.10 \\
0.09 \\
0.07\end{array}$ & $\begin{array}{l}0.20 \\
0.20 \\
0.20 \\
0.20\end{array}$ & $\begin{array}{l}0.53 \\
0.43 \\
0.45 \\
0.35\end{array}$ & $\begin{array}{l}1.67 \\
1.48 \\
1.22 \\
0.75\end{array}$ & $\begin{array}{l}9.03 \\
7.70 \\
6.07 \\
4.53\end{array}$ & $\begin{array}{l}13.45 \\
17.64 \\
16.17 \\
14.92\end{array}$ \\
\hline $\begin{array}{l}\text { F-LSD } \\
(p<0.05)\end{array}$ & 0.14 & 0.12 & 0.06 & 0.12 & 0.07 & 0.35 & 0.02 & NS & 0.09 & 0.23 & 0.85 & 1.98 \\
\hline
\end{tabular}

Table 2 shows the soil nutrient content after the first planting season. There was significant effect on the soil $\mathrm{pH}$, total nitrogen, exchangeable potassium, exchangeable magnesium and exchangeable aluminium with fertilizer application. Treatments T2 (300 kg/ha NPK $+4 \mathrm{t} / \mathrm{ha}$ PM) and T4 (400 t/ha NPK only) had the highest $\mathrm{pH}$ units (6.1) while T5 (8 t/ha PM only) had the least $\mathrm{pH}$ unit (5.8). Total nitrogen was highest $(0.42$ $\left.\mathrm{gkg}^{-1}\right)$ in T5 $\left(0.42 \mathrm{gkg}^{-1}\right)$ and least $\left(0.28 \mathrm{gkg}^{-1}\right)$ was obtained from T6 $(0 \mathrm{~kg} / \mathrm{ha} \mathrm{NPK}+0 \mathrm{t} / \mathrm{ha}$ PM. $)$. Exchangeable aluminium was highest $(0.53 \mathrm{cmolkg}-1)$ in T6 $(0 \mathrm{~kg} / \mathrm{ha} \mathrm{NPK}+0 \mathrm{t} / \mathrm{ha} \mathrm{PM})$ and least $\left(0.36 \mathrm{cmolkg}^{-1}\right)$ in T1 $(200$ $\mathrm{kg} / \mathrm{ha}$ NPK $+6 \mathrm{t} / \mathrm{ha}$ PM). The result obtained is similar to findings of Liasu et al. (2008). Similarly, lime application had significant $(\mathrm{P}<0.05)$ effect on the soil chemical properties.

Liming the soil to $\mathrm{pH} 7.0$ raised the soil $\mathrm{pH}\left(\mathrm{H}_{2} \mathrm{O}\right)$ value by $1.4 \mathrm{pH}$ units (Table 2). Low phosphorus value is expected in such an acidic soil, but its content was in the range of sufficient supply. A significant increase in available phosphorus was achieved by liming the soil to $\mathrm{pH}$ 6.0. Kovacevic and Rastija (2010) reported similar finding with the application of 10 and 15 tha $^{-1}$ dolomite. It has been reported that reducing the soil acidity leads to increased phosphorus availability (Gaume et al., 2001). However, it was observed that beyond $\mathrm{pH}$ 6.0, the available phosphorus decreased (Table 2). Lime application significantly $(\mathrm{P}<0.05)$ affected the potassium availability which decreased with increased soil $\mathrm{pH}$ levels. This is not in line the report of Kovacevic et al. (2010) who didn't find the effect of liming on potassium content with application of 10 and $15 \mathrm{t}$ dolomite $\mathrm{ha}^{-1}$.

Table 3 Residual Effect of Treatment Application on Dry Matter Yield and Plant Height

\begin{tabular}{lllll}
\hline Treatment combination & $\begin{array}{l}\text { DM } \\
(\mathbf{t} / \mathbf{H a})\end{array}$ & Leaf Area Index & Tasseling Number & $\begin{array}{l}\text { Plant Height } \\
(\mathbf{c m}) \text { at } \mathbf{8}^{\mathrm{th}} \text { week }\end{array}$ \\
\hline Fertilizer & & & & \\
T1 & 1.20 & 2.51 & 2.00 & 72.5 \\
T2 & 1.11 & 1.80 & 1.04 & 54.0 \\
T3 & 1.21 & 2.20 & 1.88 & 62.8 \\
T4 & 2.33 & 2.13 & 70.3 \\
T5 & 1.15 & 2.14 & 2.25 & 64.9 \\
T6 & 1.35 & 2.09 & 1.21 & 56.8 \\
F-LSD (p<0.05) & 1.21 & $\mathbf{0 . 3 5}$ & $\mathbf{0 . 2 9}$ & $\mathbf{9 . 4 4}$
\end{tabular}

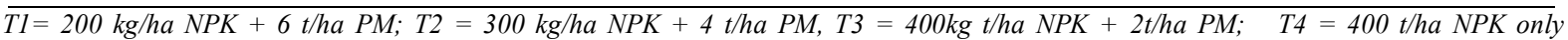
T5 = $8 \mathrm{t} / \mathrm{ha} P M$ only; $T 6=0 \mathrm{~kg} / \mathrm{ha} \mathrm{NPK}+0$ t/ha PM.

The residual effect of fertilizer application on dry matter yield and maize height is shown in Table 3. There was significant $(\mathrm{P}<0.05)$ increase in the maize dry matter yield with fertilizer application. T5 $(8 \mathrm{t} / \mathrm{ha} \mathrm{PM})$ plots recorded the highest dry matter yield $(1.35 \mathrm{t} / \mathrm{ha})$ while the least dry matter yield $(1.11 \mathrm{t} / \mathrm{ha})$ was obtained from T2 (300 kg/ha NPK + 4 t/ha PM) plots. Dry matter yield recorded from T5 (8 t/ha PM only) was higher than that recorded from T4 (400 t/ha NPK only) amended plots by $14.4 \%$. This could be attributed to the liming properties of poultry manure which may have necessitated the release of nutrients by providing a favourable soil condition. 
Similarly, there was significant increase in the maize plant height with fertilizer application. Treatment T1 (200 $\mathrm{kg} / \mathrm{ha} \mathrm{NPK}+6 \mathrm{t} / \mathrm{ha} \mathrm{PM})$ amended plots had the highest maize plant height $(72.5 \mathrm{~cm})$ while the lowest plant height $(54.0 \mathrm{~cm})$ was obtained from T2 $(300 \mathrm{~kg} / \mathrm{ha} \mathrm{NPK}+4 \mathrm{t} / \mathrm{ha} \mathrm{PM})$ amended plots. Treatment T1 $(200 \mathrm{~kg} / \mathrm{ha}$ NPK +6 t/ha PM) plots was not significantly higher than that obtained from treatments T4 (400 t/ha NPK only) and T5 ( 8 t/ha PM) amended plots. The increase in plant height with T1 application could be attributed to the optimal nutrient need for maize plant growth for the soil. This is evident in the tallest plant heights obtained which is an indication that abundant nutrient supply is directly correlated to growth.

There was significant increase in leaf area with fertilizer application (Table 3). The highest leaf area $\left(396.1 \mathrm{~cm}^{2}\right)$ was obtained from T4 (400 t/ha NPK only) while T2 (300kg/ha NPK $+4 \mathrm{t} / \mathrm{ha}$ PM) plots had the lowest leaf area $\left(314.6 \mathrm{~cm}^{2}\right)$. Except in T1 $(200 \mathrm{~kg} / \mathrm{ha} \mathrm{NPK}+6 \mathrm{t} / \mathrm{ha} \mathrm{PM})$ and T3 $(400 \mathrm{~kg} \mathrm{t} / \mathrm{ha} \mathrm{NPK}+2 \mathrm{t} / \mathrm{ha} \mathrm{PM})$, leaf area recorded from T4 plots were significantly higher than that recorded from T2 $(300 \mathrm{~kg} / \mathrm{ha} \mathrm{NPK}+4 \mathrm{t} / \mathrm{ha}$ PM), T5 (8 tha PM only) and T6 (Control) amended plots by $20.6 \%, 11.6 \%$ and $12.5 \%$ respectively. Similar trend was obtained in the maize leaf area index with T1 (200 kg/ha NPK $+6 \mathrm{t} / \mathrm{ha} \mathrm{PM})$ showing highest leaf area index (2.51) while the lowest leaf area index (1.80) was recorded in T2 (300 kg/ha NPK $+4 \mathrm{t} / \mathrm{ha}$ PM) plots. Maize tasselling number was significantly affected with fertilizer application. Treatment T5 (8 t/ha PM only) had the highest tasselling number at $8^{\text {th }}$ weeks after planting while T2 $(300 \mathrm{~kg} / \mathrm{ha} \mathrm{NPK}+4$ t/ha PM$)$ had the lowest tasselling number.

Table 4. Residual Effect of Treatment Application on Dry Matter Yield, Leaf Area Index, Tasseling Number and Plant Height

\begin{tabular}{llccc}
\hline Lime application & $\begin{array}{l}\text { DM } \\
(\mathbf{t} / \mathbf{H a})\end{array}$ & Leaf Area Index & $\begin{array}{l}\text { Tasseling } \\
\text { Number }\end{array}$ & $\begin{array}{l}\text { Plant Height } \\
(\mathbf{c m}) \text { at 8 }\end{array}$ \\
\hline pH(Lime) & & & 49.0 \\
pH 5.5 & 0.94 & 1.82 & 0.69 & 74.1 \\
pH 6.0 & 1.42 & 2.59 & 2.17 & 67.6 \\
pH 6.5 & 1.10 & 2.31 & 1.69 & 63.4 \\
pH 7.0 & 1.35 & 1.99 & 2.44 & 7.71 \\
\hline F-LSD(p<0.05) & 0.04 & 0.29 & 0.24 & \\
\hline
\end{tabular}

The residual effect of lime application at different $\mathrm{pH}$ levels on maize plant height and dry matter yield is shown in Table 4. There was significant increase in the maize dry matter yield with lime application. The highest dry matter yield ( $1.42 \mathrm{t} / \mathrm{ha}$ ) was obtained in $\mathrm{pH} 6.0$ plots while lowest dry matter yield $(0.94 \mathrm{t} / \mathrm{ha})$ was recorded from $\mathrm{pH} 5.5$ plots (control). The dry matter yield from $\mathrm{pH} 6.0$ plots was higher than that obtained from pH 5.5 plots (control) by $34 \%$. However, beyond $\mathrm{pH} 6.0$, the residual dry matter yield decreased by $22 \%$ and $5 \%$ in plots limed to $\mathrm{pH} 6.5$ and $\mathrm{pH} 7.0$ respectively. This result is similar to the findings of Onwuka et al, (2009).

Similarly, lime application at different $\mathrm{pH}$ levels significantly increased the maize plant height. The highest plant height $(74.1 \mathrm{~cm})$ was recorded from $\mathrm{pH} 6.0$ plots while the lowest plant height $(49.0 \mathrm{~cm})$ in $\mathrm{pH} 5.5$ plots (control). The increase in plant growth could be attributed to the liming potentials of $\mathrm{CaO}$ which provided basic cations especially calcium that repressed the soil acidity thereby providing a healthier environment for the release of nutrients which supported the development and growth maize. Rastija et al, (2012) ; Kovačević and Rastija (2010); Kovačević et al, (2010) reported similar result.

Maize tasselling number was significantly affected with fertilizer application. The plots with T5 (8 t/ha PM only) amendments had the highest tasselling number at $8^{\text {th }}$ weeks after planting while plots amended with T2 (300 kg/ha NPK +4 t/ha PM) also had the lowest tasselling number. Similarly, liming the soil to different $\mathrm{pH}$ levels had significant effect on the leaf area. The highest leaf area $(415.8 \mathrm{~cm})$ was obtained from plots limed to $\mathrm{pH} 6.0$ while the lowest leaf area $315.3 \mathrm{~cm}$ ) was obtained from plots limed to $\mathrm{pH} 7.0$.

Leaf area obtained from plots limed to $\mathrm{pH} 6.0$ was significantly higher than that obtained from $\mathrm{pH} 5.5$ (control), $\mathrm{pH} 6.5$ and $\mathrm{pH} 7.0$ by $19 \%, 11 \%$ and $24.2 \%$, respectively. It was observed that beyond $\mathrm{pH} 6.0$, the leaf area and the leaf area index decreased significantly. Maize tasselling number was significantly affected with lime application. Plots limed to $\mathrm{pH} 7.0$ had the highest tasselling number at $8^{\text {th }}$ weeks after planting while the control plots, $\mathrm{pH} 5.5$, had the lowest tasselling number.

The residual lime-fertilizer interaction effect on the dry matter yield (figure 1) generally shows that plots limed to $\mathrm{pH} 6.0$ had the highest dry matter yield with T5 ( 8 t/ha PM only) application followed by T2 (300 $\mathrm{kg} / \mathrm{ha} \mathrm{NPK}+4 \mathrm{t} / \mathrm{ha} \mathrm{PM}$ ) application at $\mathrm{pH}$ 7.0. The lime-fertilizer interaction effect on the dry matter yield at $\mathrm{pH} 5.5$ plots was consistently lower than those plots limed to $\mathrm{pH} 6.0, \mathrm{pH} 7.0$ and $\mathrm{pH} 6.5$ and with $\mathrm{T} 1, \mathrm{~T} 2, \mathrm{~T} 3$, T4, T5, and T6 application. 


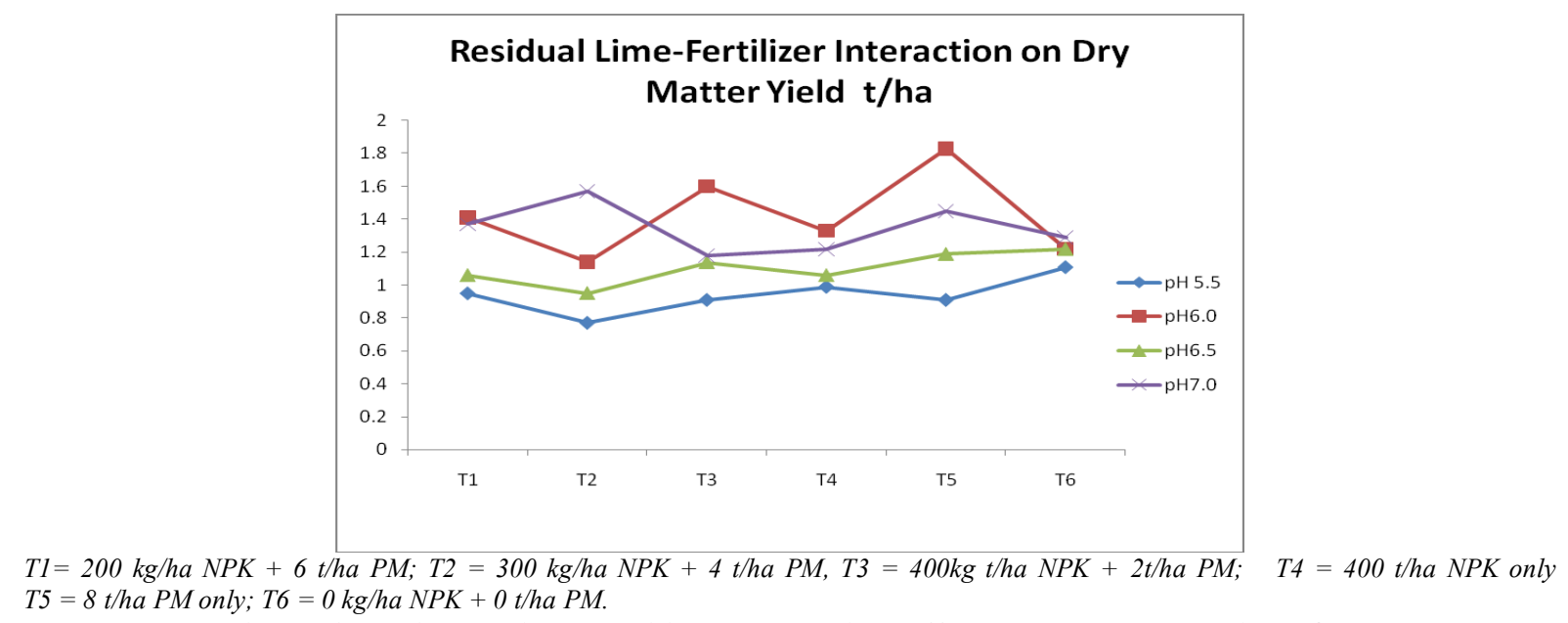

Figure 1. Residual Lime-Fertilizer Interaction Effect on Dry Matter Yield t/ha

The residual lime-fertilizer interaction effect on the leaf area index was consistently higher in plots limed to $\mathrm{pH} 6.5$ compared with plots limed to other $\mathrm{pH}$ levels as shown in figure 2 . The highest leaf area index was obtained from $\mathrm{pH} 6.0$ plots with T2 $(300 \mathrm{~kg} / \mathrm{ha} \mathrm{NPK}+4 \mathrm{t} / \mathrm{ha})$ application. $\mathrm{pH} 5.5$ plots had the least limefertilizer interaction effect on the leaf area index mostly with T1 and T5 application.

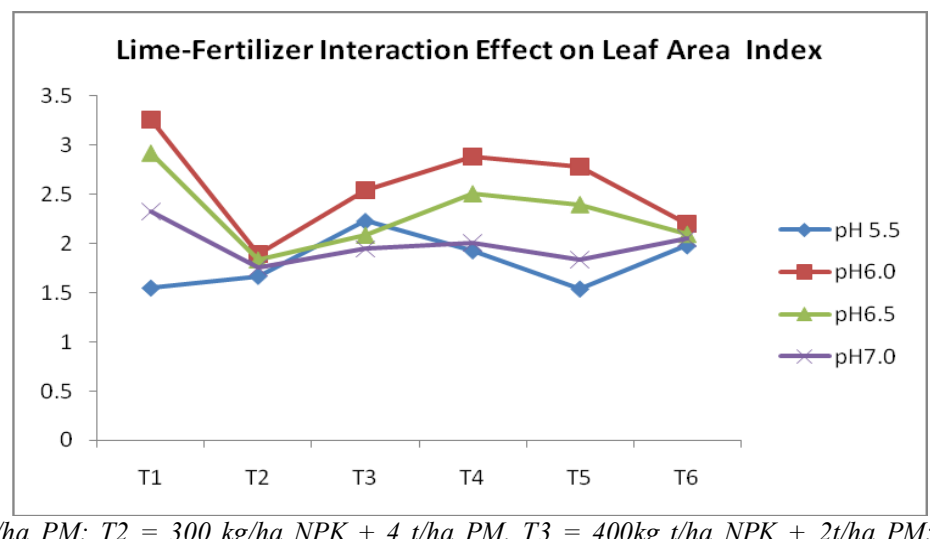

$T 1=200 \mathrm{~kg} / \mathrm{ha} \mathrm{NPK}+6 \mathrm{t} / \mathrm{ha} \mathrm{PM} ; \mathrm{T2}=300 \mathrm{~kg} / \mathrm{ha} \mathrm{NPK}+4 \mathrm{t} / \mathrm{ha} \mathrm{PM}, \mathrm{T3}=400 \mathrm{~kg} \mathrm{t} / \mathrm{ha} \mathrm{NPK}+2 \mathrm{t} / \mathrm{ha} \mathrm{PM} ; \quad \mathrm{T4}=400 \mathrm{t} / \mathrm{ha} \mathrm{NPK} \mathrm{only}$ $T 5=8 \mathrm{t} / \mathrm{ha}$ PM only; T6 $=0 \mathrm{~kg} / \mathrm{ha} N P K+0 \mathrm{t} / \mathrm{ha} P M$.

Figure 2. Residual Lime-Fertilizer Interaction Effect on Leaf Area Index

Also, pH 5.5 plots consistently had the least interaction effect on the maize plant height with fertilizer application (Figure 3). This trend was similar to that observed in the lime-fertilizer interaction on maize leaf area index and dry matter yield.

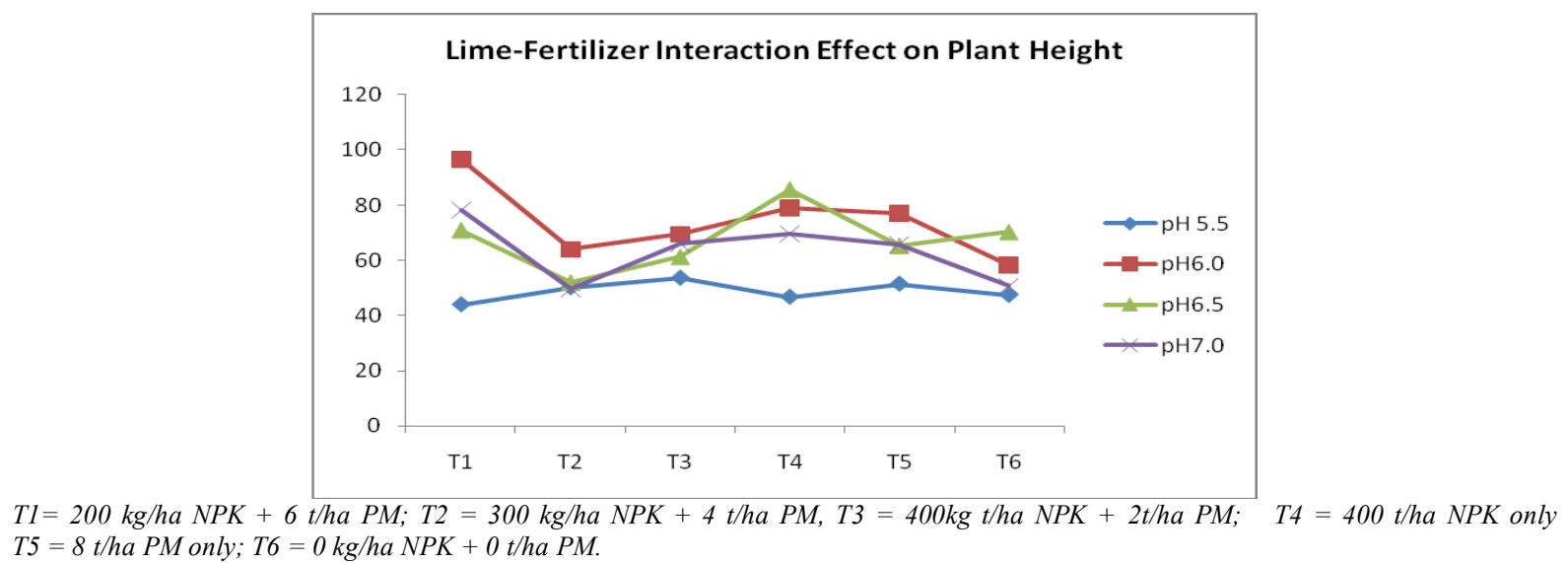

Figure 3. Residual Lime-Fertilizer Interaction Effect on Plant Height 
Similarly, pH 6.0 plots maintained the highest interaction effect on plant height with all the fertilizers rate applied except at $\mathrm{T} 4$ and $\mathrm{T} 6$.

\section{Conclusion}

Liming the soil to different $\mathrm{pH}$ levels significantly $(\mathrm{P}<0.05)$ affected the soil chemical properties especially soil $\mathrm{pH}$, organic matter, exchangeable aluminum and plant available $\mathrm{P}$ status. Similarly, fertilizer application affected the soil chemical properties. Treatment T2 $(8 \mathrm{t} / \mathrm{ha} \mathrm{PM}$ only) significantly $(\mathrm{P}<0.05)$ gave the highest dry matter yield while T2 $(300 \mathrm{~kg} / \mathrm{ha} \mathrm{NPK}+4 \mathrm{t} / \mathrm{ha} \mathrm{PM})$ had the least dry matter yield. Liming also increased the maize dry yield with soil limed to $\mathrm{pH} 6.0$ having the highest dry matter. It is therefore concluded that liming an ultisol to $\mathrm{pH} 6.0$ with the application of $8 \mathrm{t} / \mathrm{ha} \mathrm{PM}$ will support maize production without any fertilizer application in the second planting season.

\section{References}

[1] Akamigbo, F. O. R. and Igwe, C. A. (1990). Physical and chemical characteristics of four gullied soil location in Anambra state, Nigeria. Niger. Agric. J. 25: $29-48$.

[2] Anderson, J. M. And J.S.I Ingram (1993). Tropical soils biology and fertility. A handbook of methods, $2^{\text {nd }}$ Ed; CAB International, Wallingford U.K. pp 221.

[3] Antunović, M. (2008): Liming influences on maize and sugar beet yield and nutritional status. Cereal research Communications 36 (Supplementum): 1839-1842.

[4] Asadu, C. L. A. (2002). Comparative evaluation of the contributions of soil physiochemical properties to variations in the yield of flour major staple food crops in eastern Nigeria. Soil and Tillage Research 65: $141-155$.

[5] Baligar, V. C. and Fageria, N. K. (1997). Nutrient use efficiency in acid soils: nutrient management and plant use efficiency. In: Plant Soil Interactions at Low pH, A. C. Moniz et.al (ed.) 75-95.

[6] Beukes, D. J. (2000). The management of acid soils. Institute for Soil, Climate and Water. Agricultural Research Council. South Africa.

[7] Bray, R. H.and Kurtz, N. T. (1945). Determination of total organic and available form of phosphorus in soil. Soil Sci. 59: 39 - 45

[8] Bremner, J. M. (1996). Nitrogen-total. P.1085-1121. In: D. L. Sparks (Ed). Methods of Soil Anaysis, Part III. Chemical methods. SSSABook series No. 5. Am. Soc. of Agron. Madison, W. I.

[9] Buresh, R.J., Smithson, P.C. and Hellums D.T. (1997), Building soil phosphorus capital in Africa. In: Buresh P.J., Sanchez P.A. and Calhoun F. Replenishing soil fertility in Africa. SSSA Special Publication No.51. Madison Wisconsin, pp. 111-149.

[10] Fageria, N. K. and Baligar, V.C. (2008). Ameliorating soil acidity of tropical Oxisols by liming for sustainable crop production. Adv. Agron., 99:345-431.

[11] Fontes, M. P. F. \& Weed, S. B. (1996). Phosphate adsorption by clays from Brazilian Oxisols: relationships with specific surface area and mineralogy. Geoderma 72:37-51.

[12] Foy, C.D. (1984): Physiological effects of hydrogen, aluminum, and manganese toxicities in acid soil. In: Soil Acidity and Liming. Adams, F. (ed.). American Society of Agronomy, Inc., Madison, WI. 57-97.

[13] Gaume, A., Machler, F., De Leon, C., Narro, L., Frossard,E. (2001). Low-P tolerance by maize (Zea mays L.) genotypes: significance of root growth, and organic acids and acid phosphatase root exudation. Plant and Soil 228:253-264.

[14] Kisinyo Peter, Gudu Samuel, Othieno Caleb, Okalebo John, Ochuodho Julius, Agalo Joyce, Ng'etich Wilson, Opala Peter, Maghanga Justin, Osiyo Richard and Ligeyo Dickson. (2009). Residual effects of lime and phosphorus applications on soil and maize (Zea mays L.) performance in a Kenyan highlands acid soil. Journal of Agriculture, Pure and Applied Science and Technology ISSN 2073-8749.

[15] Kisinyo, P.O. Othieno, C.O. Okalebo, J.R., Kipsat, M.J., Serem, A.K. and Obiero, D.O. (2005), Effects of lime and phosphorus application on early growth of leucaena in acid soils. Proceedings of the $7^{\text {th }}$ African Crop Science Conference, Vol. 7:1233-1236

[16] Kovačević, V. and Mirta Rastija (2010). Impacts of liming by dolomite on the maize and barley grain yields. poljoprivreda 16: (2) $3-8$.

[17] Kovačević, V., Andrić, L., Banaj, D., Jambrović, A. (2010): Impacts of liming on maize and soil status. Novenytermeles 59(Suppl.): 61-64

[18] Kovacevic, V., Banaj, D., Kovacevic, J., Lalic, A., Jurkovic, Z., Krizmanic, M. (2006a): Influences of liming on maize, sunflower and barley. Cereal Research Communications 34(1 Part 2): 553-556.

[19] Liasu, M. O., Ogundare, A. O. and Ologunde, M. O. (2008). Effect of soil supplementation with fortified Tithonia mulch and directly applied inorganic fertilizer on growth and development of potted okra plants. American- Eurasian Journal of sustainable Agriculture, 2(3): 264- 270, 2008.

[20] Lindsay, W.L. (1979). Chemical Equilibria in Soils, John Wiley \& Sons, New York.

[21] Lungu, O.I., Temba, J., Chirwa, B. and Lungu, C. (1993), "Effects of Lime and Farmyard Manure on Soil Acidity and Maize Growth on an Acid Alfisol from Zambia": Tropical Agriculture, vol. 70,no. 4, pp. 309-313.

[22] Naidu, R. Syers, J.K.. Tillman R.W and Kirkman, J.H. (1990). Effect of liming and added phosphate on charge characteristics of acid soils, J. Soil Sci. 41, pp. 157-164.

[23] Onwuka, M. I., Osodeke, V. E. and Ano, A.O2009. Use of Liming Materials To Reduce Soil Acidity And Affect Maize (Zea mays L) Growth Parameters In Umudike, Southeast Nigeria. PAT; 5 (2):386-396

[24] Rastija, M., Šimić, D., Lalić, A. (2010): Impacts of liming with dolomite on maize, wheat and barley yields. Novenytermeles 59(Suppl.): 65-68).

[25] Rengel Z. (2003). Handbook of Soil Acidity (ed.). Marcel Dekker, Inc. New York, Basel.

[26] Rastija, D., Z. Semialjac, M. Rastija, A. Gulisija (2012). Residual Effect of Liming on Soil Properties and Maize Grain Yield. Third International Scientific Symposium "Agrosym Jahorina

[27] Sauve, S. Martinez, C.E. McBridge M.and Hendershot, W. (2000). Adsorption of free lead (Pb ${ }^{2+}$ ) by pedogenic oxides, ferrihydrite, and leaf compost, Soil Sci. Soc. Am. J. 64: 595-599.

[28] Shainberg, I., Sumner, M. E., Miller, W. P., Farina, M. P. W., Pavan, M. A. and Fey, M. V. (1989). Use of gypsum on soils: A review. In Stewart, B. A. (ed.) Advances in Soil Science. Vol. 9. Pp. 111. 
[29] Shoemaker, H. E., McLean, E. O. and Pratt, P. F. (1961). Buffer methods for determinine lime requirement of soils with appreciable amounts of extractable aluminium. Soil Sci. Soc. Of Am. Proc., 25, 274-277.

[30] The, C., Calba H., Zonkeng, C., Ngonkeu, E.L.M. and Adetimirin, V.O. (2006), Response of maize grain yield to changes in acid soil characteristics after soil amendment. Plant soil, 284:45-57.

[31] Tisdale, S. L., Nelson W. L., Beaton, J. D. Havlin J. L. (1993). Soil fertility and fertilizers. 5thedition. Macmillan Publishing company, New York, U.S.A.

[32] Walkley, A. and Black, I. A. (1934). An examination of the degtjareff methods for determining soil organic matter and a proposed modification of the chronic acid titration method. Soil Sc. Journal 37: $29-38$. 